\title{
Analysis on the Relationship of New Type International Trade and Foreign Direct Investment
}

\author{
Yan Wan ${ }^{1}$, Lifang Wang ${ }^{1}$ \\ ${ }^{1}$ Nanchang Institute of Science \& Technology, Nanchang, Jiangxi, 330000
}

Keywords: international trade; foreign direct investment; new type; finance

\begin{abstract}
On the impact of foreign-invested enterprises and the expansion of China's trade, this paper discusses three aspects of FDI (foreign direct investment) in China's foreign trade and China's bilateral trade, based on the actual development of China, and conducts an empirical study on the complementary relationship between FDI and international trade, with quantitative analysis, to further make use of foreign direct investment and promote economic growth.
\end{abstract}

\section{Introduction}

Since the 1980s, what has been the relationship between the introduction of foreign direct investment (hereinafter referred to as FDI) and the international trade volume in China? What is the relationship between the two? This article is based on the actual situation in China Empirical analysis of the relationship between FDI and international trade. Traditional FDI theory and international trade theory are developed separately, but in the past 30 years, scholars have tried hard to integrate the theory of international trade and FDI theory, representative of the Victoria farmers (Vemon, 1966), at the core of its theory is that direct investment and benefits to investors can only happen by combining the unique advantages that businesses have with the location advantages that firms derive from a given host country. The theory of marginal industrial expansion of scholar Kojima $(1973,1985)$ argues that the analysis of the causes of international direct investment should be conducted in the perspective of macroeconomic factors, especially the principle of international division of labor, so as to link outward foreign investment with foreign investment Trade is organically integrated [1].

\section{Empirical Analysis of the Relationship between FDI and International Trade}

The framework analyzed in this paper is the use of gravity model. Gravity model is one of the most successful application models in the field of international trade and has been widely used in the study of international direct investment. The basic idea of this model is that the size of the country's economy and the two countries The distance between them is the most important factor that affects international trade. In addition, we can add dummy variables to analyze specific problems.

$($ Tij $)=\alpha+\beta 1 \ln (Y i Y j)+\beta 2 \ln [(Y / N) i(Y / N) j]+\beta 3 \ln (D I S T i j)$ where Tij is the trade volume between country i and country j; GNP; Y / N GNP per capita; DISTij is the distance between two countries.

According to the idea of gravity model, the bilateral trade volume model between China and its trading partners is described as follows: $\mathrm{BTcj}=\beta 0 \mathrm{Xc} \beta 1 \mathrm{Xj} \beta 3 \mathrm{RC} \beta 4 \mathrm{j}$.

Here, BTcj refers to the bilateral trade volume between China (C) and the country (j); Xc refers to the influencing factor of China $(\mathrm{C})$; Xj refers to the influencing factor of country $(\mathrm{j})$; and $\mathrm{Rcj}$ refers to the connecting factor.

According to the idea of gravitation model, the basic model of trade volume between China's provinces and other countries in the world is as follows: $\ln \mathrm{Ti} *=\beta 0+\beta 1 \ln \mathrm{Xi}+\beta 2 \ln \mathrm{Ri} *$

Where $\mathrm{Xi} *$ is the total trade volume between province $\mathrm{i}$ and other countries in the world, $\mathrm{Xi}$ is the factor of province $\mathrm{i}$, and $\mathrm{Ri} *$ is the link factor. The total trade volume between China's provinces and other countries in the world is estimated to include the following variables: 1) (Ti *) i 
Provinces (the sum of the import and export trade of the provinces in the United States dollar against the world in United States dollars, regardless of the volume of trade between the provinces); 2) Provinces of the size (POPi) i (PYi) i Province's per capita income (i province per capita income, per capita income and the province's per capita income in the province's total population (the province's population and the province's total foreign trade is positively related to the relationship); 3) 4) The relative distances between provinces (RMTi) i The center of gravity of provincial average distances to all countries in the world (the distance coefficient is negatively related to the impact of the total trade volume between the province and the world) 5) Foreign Direct Investment (FDIi *) The total foreign stock of foreign-invested enterprises in province i (the total foreign investment in each province calculated in USD by FIEs and the total investment stock of FIEs are positively related to the province's trade volume) [2].

We establish the following equation to determine the effect of FDI on bilateral trade between China and its trading partners: $\operatorname{lnBTcj}=\beta 0+\beta 1 \ln$ GDPscj $+\beta 2 \operatorname{lnDISTcj}+\beta 3 \ln F D I c j+\varepsilon j$, where $\varepsilon j$ is the stochastic disturbance factor, $\beta \mathrm{s}$ is the regression parameter used for the prediction and the variables are in Has been defined above.

A sample regression analysis of the covariance matrix containing white noise using the least squares method (OLS) was used to analyze the unknown noise structure Data collected for bilateral trade with other countries was collected in 1995, 1996, 1997 and 1998, using this data to explain the interpretation The meaning of variables.

The regression results show that the higher the stock of FDI in China by China's trading partners is, the greater the bilateral trade between China and it will be. The correlation of FDI is estimated to be between 0.10 and 0.12 in the four years from 1995 to 1998, indicating that in the 20th century for every 1\% increase in the stock of FDI in the early 1990s, the trade volume between China and its trading partners will increase by $0.11 \%$.

Before we conclude the regression results, we use the eigenvalue test to prove the trade volume between the provinces in the forecasting model and other countries in the world (the test process is omitted). The test results show that the linear correlation between the trade volume in each province and most of the eigenvalues Therefore, there are sufficient reasons to accept this model that reflects the trade volume between the provinces and the rest of the world. According to our test of the eigenvalues of the forecasting model, we can get some conclusions from the results, the regression results are very good, the model provides of independent variables can well explain the relationship between the total trade volume of various provinces in China and other countries in the world. The regression statistics show that the impact of FDI on the trade volume of all provinces is positively correlated and the correlation coefficient of FDI increases with time in these nine years, indicating that the impact of FDI on trade in various provinces plays an increasingly important role from the early 1990s through the late 1990s. The correlation coefficient of FDI shows that at the end of 1980, each province's FDI stock rose by $1 \%$ The increase in total volume was less than $0.2 \%$, but by $1 \%$ for each $1 \%$ increase in the stock of FDI in each province, the total volume of trade in all provinces increased by more than $0.3 \%$ by the end of 1990. Therefore, Empirical analysis of trade demonstrations across provinces again shows that the impact of FDI on trade is positively correlated, and empirical analysis based on the total volume of trade in various provinces shows that FDI plays a positive role in promoting trade among provinces in China.

\section{Some Inspirations of New Relationship between International Trade and Foreign Direct Investment in China}

Since the reform and opening up, China's foreign trade has developed rapidly and has become an important force driving economic growth. In 1997, China's total import and export volume reached 352.2 billion U.S. dollars, surpassing 400 billion U.S. dollars in 2000, surpassing 400 billion U.S. dollars in 2001 and 68.28 billion U.S. dollars in 2003, continuing to rise to a new level. The share of China's exports in world exports was 5\% in 2002 and the world trade ranking in 2002 was the fifth in the world. After China's accession to the WTO, the trading environment has undergone tremendous changes, creating favorable conditions for the development of China's export trade. 
However, it should be noted that the development and changes in the world economic form have also posed great challenges to the development of China's foreign trade. This concentrated on the fact that with the further aggravation of trade frictions among countries in the world, trade protectionism has tended to be intensified. From the perspective of our country's international environment, due to various reasons such as ideology and trade policies, the trade environment in our country is not optimistic. In recent years, China's export products in the international market repeatedly anti-dumping fully illustrates this point. In this form, actively seeking solutions to promote the development of foreign trade has become an important task facing our country's economic development. From the foregoing analysis, we can see that due to the strong complementary relationship between export trade and OFDI and the small share of China's direct investment abroad in comparison with the trade volume, the proportion of these countries in 1995 They are: Argentina 7\%, Australia 7\%, Brazil 3\%, France 6\%, the United States 16\%, Canada 6\%, Britain $18 \%$, the Netherlands 1\%, Japan 5\%, South Korea 3\% with an average of $6.4 \%$. While China is $1 \%$ year on year, much lower than the average. Under such circumstances, it is necessary and possible to promote the development of export trade by accelerating overseas direct investment [3].

Through direct investment abroad, on the one hand, it can absorb and absorb traditional technologies and transfer surplus production capacity to promote the adjustment of industrial structure and product structure; on the other hand, industries and technologies with comparative advantages will be spread to developing countries and even developed countries, can lead our country's technical equipment, labor and goods exports. It is particularly worth mentioning that OFDI is conducive to enhancing the export of manufactured products in our country, especially mechanical and electrical products. In general, OFDI can promote the export of equipment and intermediate products in the following ways. (1) The Chinese side invests in equipment at a price, which is favorable for the export of equipment in our country. (2) export through equipment renewal and matching requirements; (3) export through the supply of raw materials and intermediate products to overseas enterprises. (1) The practice of our country's enterprises in recent years also confirmed that OFDI promoted the export of China's mechanical and electrical products and intermediate products. After more than 20 years of reform and opening up, our country also possesses the conditions for expanding foreign investment. First of all, since the reform and opening up, China's national economy has witnessed tremendous achievements in its rapid development. The overall national strength and international competitiveness continue to increase, and foreign trade and foreign exchange reserves continue to grow. Our foreign exchange reserves rose from \$ 139.9 billion in 1997 to \$ 286.4 billion in 2002. At the same time, some overseas enterprises that have earlier gone abroad have, after years of development, continuously strengthened their capabilities and gradually enriched their experience and gradually developed and expanded into groups of enterprises with strong international competitiveness. This has laid a solid material foundation for our country to expand and speed up overseas direct investment. From the reality of China, it also possesses the advantages of overseas direct investment. First, the practical advantages of technology. Generally speaking, the technological level of our country lags behind that of developed countries, but this does not mean that our country does not possess the technological superiority. Our country has a large number of applicable technologies that are easily accepted by a large number of developing countries, such as small-scale production technology and labor-intensive Production technology and equipment, etc. Our country enjoys unique advantages in some traditional industries, such as traditional Chinese medicine and foodstuffs. Our country has some leading advantages in some high-tech fields. For example, in the fields of space technology and computer software, China is in the leading position in the world Level. These technological advantages constitute an important foundation for China's outward direct investment. Second, management advantages. Due to the similar historical background and level of economic development, Chinese enterprises have relatively high affinity with the local community when they invest in developing countries. Compared with Western managers, managers in Chinese enterprises are more tolerant and more likely to communicate with employees. Which has a certain 
management advantage. Third, China has a good international reputation. The international image and international reputation of a country play an important role in a country's foreign economic activities. The Chinese government has always pursued peaceful diplomacy and equal diplomacy and opposed the plundering and monopolizing of the international economy. It not only won the trust and support of the vast majority of developing countries, but also won the cooperation of many developed countries. Many countries and regions in the world are willing to develop economic cooperation with our country, including investing and building factories in their countries [4].

\section{Conclusion}

With the continuous development and changes of China's foreign investment policies, the promotion effect of FDI on import and export will be weakened. Meanwhile, the domestic market share of foreign-invested enterprises will continue to expand, and we should recognize that the growth of FDI in a country Of the role is many. In the export-led growth model, the promotion of import and export of FDI is important, but rely on foreign trade growth can not long-term support for economic growth. At present China's economic development is the main task of transforming economic growth in the aspect of introducing foreign capital, it is embodied in the aspects of using foreign capital to upgrade our country's technological level, perfecting the market mechanism and industrial structure, and promoting the development of human resources. This is exactly what we will study next [5].

\section{References}

[1] BRIAN J AIKEN, ANN E HARRISON. Do Domestic Firms Benefit from Direct Foreign Investment? Evidence from Venezuela [J]. The American Economic Review, 1999 (6): 60-65.

[2] Yang Z. Analysis of the impact of foreign direct investment on China's import and export [J]. World Economy, 2000 (2): 44-49.

[3] Zhongzheng Yan Correctly understand the relationship between the utilization of foreign capital and the protection of national industry in China [J]. Management World, 1998 (1): 40-44.

[4] Xian Xiacan. Capital Flows and Globalization: Capital Inflow and its Implications from China [J]. World Economy \& China, 2000 (3-4): 24-32.

[5] Shen Kunrong. Ph D Capital Inflow and Economic Growth in China [J]. World Economy \& China, 2000 (1-2): 40-45. 